\title{
Anti-rheumatic effects of Aconitum leucostomum Worosch. on human fibroblast-like synoviocyte rheumatoid arthritis cells
}

\author{
JUNLING YANG ${ }^{1}$, FEICUI ZHAO ${ }^{2}$ and JIHONG NIE ${ }^{2}$ \\ ${ }^{1}$ College of Traditional Chinese Medicine, Xinjiang Medical University, Urumqi, Xinjiang 830011; ${ }^{2}$ Department of \\ Pharmacy, Chinese Medicine Hospital Affiliated to Xinjiang Medical University, Urumqi, Xinjiang 830000, P.R. China
}

Received March 8, 2016; Accepted March 3, 2017

DOI: $10.3892 /$ etm.2017.4503

\begin{abstract}
The aim of the present study was to investigate the effects of Aconitum leucostomum Worosch. crude drug, processed products and monomer components on human fibroblast-like synoviocyte rheumatoid arthritis (HFLS-RA) cells, and its associated mechanisms. Following drug treatment, cell proliferation was assessed using a Cell Counting Kit- 8 assay. Cellular apoptosis and cell cycle were evaluated using flow cytometry. Levels of hypoxia-inducible factor $1 \alpha$ (HIF-1 $\alpha$ ), vascular endothelial growth factor (VEGF) and toll-like receptor 4 (TLR4) mRNA and protein were evaluated using reverse transcription-quantitative polymerase chain reaction (RT-qPCR) and western blot analysis, respectively. Levels of pro-inflammatory cytokines were evaluated using ELISA. Analysis of cell proliferation indicated that crude drug and processed products markedly inhibited the cell proliferation. Compared with the control group, the apoptosis rates were significantly elevated in all treatment groups (all $\mathrm{P}<0.05)$. Furthermore, the proportion of cells in $\mathrm{G} 0 / \mathrm{G} 1$ phase was significantly decreased in all treatment groups compared with the control group (all P<0.05). RT-qPCR and western blotting indicated that, compared with the control group, mRNA and protein expression levels of HIF- $1 \alpha$, and TLR4 were significantly downregulated in all treatment groups $(\mathrm{P}<0.05)$. The mRNA and protein expression levels of VEGF in all treatment groups were decreased compared with those in the control group, but the difference was not significant. Results from ELISA demonstrated that the levels of interleukin (IL)-6, IL-1 $\beta$ and tumor necrosis factor- $\alpha$ in the cell culture supernatant were all significantly decreased following drug treatment in HFLS-RA cells (all $\mathrm{P}<0.05$ ). Therefore,
\end{abstract}

Correspondence to: Dr Jihong Nie, Department of Pharmacy, Chinese Medicine Hospital Affiliated to Xinjiang Medical University, 116 Yellow River Road, Urumqi, Xinjiang 830000, P.R. China

E-mail: xjnjh411@163.com

Key words: Aconitum leucostomum Worosch., anti-rheumatic effects, crude drug, processed products, monomer components, human fibroblast-like synoviocyte rheumatoid arthritis cells
A. leucostomum Worosch. crude drug, processed products and monomer components may exert anti-rheumatic effects on HFLS-RA cells, inhibiting cell proliferation and enhancing cellular apoptosis. These effects may be attributable to the downregulated expression of HIF-1 $\alpha$ and TLR4, as well as decreased levels of pro-inflammatory cytokines.

\section{Introduction}

Rheumatoid arthritis (RA) is an inflammatory autoimmune disease characterized by synovitis and pannus formation, which causes severe pain and seriously affects patient quality of life (1). Synovial tissue is principally composed of fibroblast-like synovial cells, which are closely associated with the pathogenesis and development of RA, particularly joint damage. Fibroblast-like synovial cells may secrete pro-inflammatory cytokines, chemokines and matrix protein-degrading enzymes $(2,3)$. These factors may cause an imbalance in the proliferation and apoptosis of synovial cells, and induce abnormalities in signal transduction in synovial tissue (4), resulting in the inflammation and destruction of joints.

It has been reported that RA-related joints are associated with a hypoxic microenvironment (5), which regulates angiogenesis, induces inflammatory cell infiltration and elevates pro-inflammatory factor production (6,7). Hypoxia-inducible factor- $1 \alpha$ (HIF-1 $\alpha)$ is an important regulatory factor for the hypoxic response. Under hypoxic conditions, HIF-1 $\alpha$ may activate and upregulate the expression of hypoxic adaptation-related genes, which are involved in energy metabolism, intracellular signal transduction and angiogenesis processes in RA fibroblasts (8). Furthermore, vascular endothelial growth factor (VEGF) is a potent angiogenesis-stimulating factor, which serves key roles in angiogenesis and pathogenesis of RA (9). Toll-like receptors (TLRs) are regulators of adaptive immune responses (10). Activated TLRs may induce the antimicrobial defense system to produce interleukin (IL)-6, IL-1 $\beta$, tumor necrosis factor- $\alpha$ (TNF- $\alpha$ ) and other chemokines, thought to be involved in the pathogenesis of RA (11). TNF- $\alpha$ is an inflammatory mediator with multiple biological roles. It is primarily produced by mononuclear macrophages and serves a critical function in the pathogenesis and development of RA. Furthermore, it may stimulate the proliferation of synovial fibroblasts, as well as the secretion of IL-6, granulocyte-macrophage colony stimulating factor, chemokines, 
matrix metalloproteinases and prostaglandin (12). At present, there are a number of commercially available TNF- $\alpha$ antagonists that may be used to treat RA $(13,14)$; however, long-term usage of TNF- $\alpha$ antagonists may induce drug resistance and cause infection (15).

Aconitum leucostomum Worosch. is a perennial herb belonging to the family Ranunculaceae and is primarily found in Gansu, Xinjiang and northeastern areas of China (16). The root of A. leucostomum Worosch. is commonly used in Kazak medicine for the treatment of indigestion and pain $(17,18)$. In particular, A. leucostomum Worosch. root has been reported to be an effective treatment of rheumatic diseases $(19,20)$. A previous study by the current authors demonstrated that A. leucostomum Worosch. could alleviate the inflammatory response in the joints of rats with adjuvant arthritis (21). However, the detailed mechanism of this effect has not yet been fully elucidated. In the current study, the effects of A. leucostomum Worosch. crude drug, processed products and monomer components on in vitro human rheumatoid fibroblast-like synoviocyte RA (HFLS-RA) cells were investigated. The levels of HIF-1 $\alpha$, VEGF and TLR4, as well as the related pro-inflammatory cytokines, were analyzed and discussed.

\section{Materials and methods}

Cell line and cell culture. Human fibroblast-like synoviocyte rheumatoid arthritis (HFLS-RA) cells were purchased from the European Collection of Authenticated Cell Cultures (Porton Down, UK). These cells were cultured in DMEM medium (Gibco; Thermo Fisher Scientific, Inc., Waltham, MA, USA) containing $10 \%$ fetal bovine serum (Gibco; Thermo Fisher Scientific, Inc.) at $37^{\circ} \mathrm{C}$ in an incubator containing $25 \% \mathrm{CO}_{2}$.

Drug preparation and administration. A. leucostomum Worosch. $(\sim 30 \mathrm{~kg})$ was obtained from Nilka County (Yili, Xinjiang, China) and identified by pharmacist Professor Yonghe Li at the Traditional Chinese Medicine Hospital Affiliated to Xinjiang Medical University (Urumqi, China). Monomer components were isolated and purified according to our previously published procedures, and identified to be delvestidine (WF-1) and anthranoyllycoctonine (WF-4), according to spectral analysis (22). Three kinds of processed products were prepared using water-boiling, high-pressure steaming and excipient co-boiling methods, respectively (23).

Decoction solution of the crude drug and processed products was prepared as previously reported (24). Briefly, $200 \mathrm{~g}$ crude drug or processed product was immersed in water $(\mathrm{w} / \mathrm{v}=1 / 8)$ for $1 \mathrm{~h}$, then boiled for $30 \mathrm{~min}$. Following filtration with 4 layers of bandage, the solution was collected and subjected to another decoction. Three decoctions were performed in total. Then, $40 \%$ (v/v) ethanol (95\%) was added to the decoction solution, which was kept at $4^{\circ} \mathrm{C}$ for 2 days. Following centrifugation $700 \mathrm{x} \mathrm{g}$ at room temperature for $10 \mathrm{~min}$, the supernatant was concentrated under reduced pressure in a $65^{\circ} \mathrm{C}$ water bath and dry extract was obtained.

For drug administration, HFLS-RA cells were divided into the following groups: i) Control group, in which the cells received no treatment; five treatment groups, in which the cells were treated with ii) $2 \mathrm{mg} / \mathrm{ml}$ crude drug, iii) $1.8 \mathrm{mg} / \mathrm{ml}$ water-boiled processed products, iv) $1.5 \mathrm{mg} / \mathrm{ml}$ high-pressure steamed processed products, v) $1.2 \mathrm{mg} / \mathrm{ml}$ excipient co-boiled processed products, vi) $40 \mu \mathrm{g} / \mathrm{ml}$ monomer component WF-1 or vii) $100 \mu \mathrm{g} / \mathrm{ml}$ monomer component WF-4; and viii) a positive control group, in which cells were treated with $150 \mu \mathrm{g} / \mathrm{ml}$ leflunomide, which is used for the treatment of RA (25) (Sigma-Aldrich; Merck KGaA, Darmstadt, Germany). For the drug treatment, WF-1, WF-4, and leflunomide were dissolved in DMSO, and dry drug extracts were dissolved in the DMEM medium, which were then used to incubate the cell cultures, respectively. The inhibition rates were calculated based on the data from the control group.

Cell Counting Kit-8 (CCK-8) assay. HFLS-RA cells were plated onto a 96-well plate at a density of $1 \times 10^{4}$ cells/well. Following drug treatment, $20 \mu \mathrm{l} \mathrm{CCK-8} \mathrm{solution} \mathrm{(FC101-03;}$ BestBio, Shanghai, China) was added to each well and the cells were incubated at $37^{\circ} \mathrm{C}$ for $4 \mathrm{~h}$. The absorbance at $450 \mathrm{~nm}$ was read using a spectrophotometer (xMark; Bio-Rad Laboratories, Inc., Hercules, CA, USA).

Flow cytometry. Cellular apoptotic process and cell cycle stages were evaluated using flow cytometry. For the apoptosis assessment, cells were washed with PBS, and then digested with $1 \mathrm{ml} 0.25 \%$ trypsin. Following centrifugation at $350 \mathrm{xg}$ for $5 \mathrm{~min}$, cells were resuspended in pre-cooled PBS. Apoptosis detection was performed with the Annexin V-FITC kit (cat. no. BB-4101-3; BestBio) using the MACSQuant flow cytometer (Miltenyi Biotec GmbH, Bergisch Gladbach, Germany). For cell cycle detection, following drug treatment, cells were collected and centrifuged at $37^{\circ} \mathrm{C}$ at $350 \mathrm{x} \mathrm{g}$ for $5 \mathrm{~min}$. Following PBS washing and centrifugation, cells were treated with pre-cooled $70 \%$ ethanol and stored at $4^{\circ} \mathrm{C}$ overnight. The cells were then centrifuged at $37^{\circ} \mathrm{C}$ at $350 \mathrm{x}$ for $5 \mathrm{~min}$ and stained with $0.5 \mathrm{ml}$ propidium iodide solution at $37^{\circ} \mathrm{C}$ in the dark for $30 \mathrm{~min}$. Fluorescence was detected using the MACSQuant flow cytometer with MACSQuantify software (Miltenyi Biotec, Auburn, CA, USA).

Reverse transcription-quantitative polymerase chain reaction (RT-qPCR). Levels of HIF-1 $\alpha$, VEGF and TLR4 mRNA were evaluated using RT-qPCR. Total RNA was extracted from cells using TRIzol (Sigma-Aldrich; Merck KGaA). cDNA was obtained using a FastQuant RT kit with gDNase (cat. no. KR106-02; Tiangen Biotech Co., Ltd., Beijing, China). Quantitative PCR was performed with the SYBR Select Master mix (cat. no. 4472920; Applied Biosystems; Thermo Fisher Scientific, Inc.) on a 7500 qPCR instrument (Applied Biosystems; Thermo Fisher Scientific, Inc.). The primer sequences were as follows: HIF-1 $\alpha$, forward, 5'-TTTGGCAGC AACGACACAGA-3' and reverse, 5'-TTTCAGCGGTGGGTA ATGGA-3'; VEGF, forward, 5'-GGCCTCCGAAACCATGAA CT-3' and reverse, 5'-TCCATGAACTTCACCACTTCGT-3'; TLR4, forward, 5'-ACAACCTCCCCTTCTCAACC-3' and reverse, 5'-TTGTCTGGATTTCACACCTGG3'; and GAPDH, forward, 5'-TGTTGCCATCAATGACCCCTT-3' and reverse, 5'-CTCCACGACGTACTCAGCG3'. Amplification conditions were as follows: Denaturation at $95^{\circ} \mathrm{C}$ for $2 \mathrm{~min}$, followed by 40 cycles of $95^{\circ} \mathrm{C}$ for $15 \mathrm{sec}$ and $60^{\circ} \mathrm{C}$ for $1 \mathrm{~min}$, followed by extension at $50^{\circ} \mathrm{C}$ for $2 \mathrm{~min}$. The relative expression levels of target genes were calculated using the $2^{-\Delta \Delta C q}$ method (26). 
Table I. Effect of Aconitum leucostomum Worosch. on the proliferation of human fibroblast-like synoviocyte rheumatoid arthritis cells.

\begin{tabular}{lccccccc}
\hline & & & & & \multicolumn{3}{c}{$\begin{array}{c}\text { Inhibition rate } \\
\text { at } 1 / 2 \mathrm{IC}_{50}(\%)\end{array}$} \\
\cline { 4 - 7 } Treatment & $\begin{array}{c}\text { Concentration } \\
(\mathrm{mg} / \mathrm{ml})\end{array}$ & $\begin{array}{c}\text { Inhibition } \\
\text { rate }(\%)\end{array}$ & $\begin{array}{c}\mathrm{IC}_{50} \\
(\mathrm{mg} / \mathrm{ml})\end{array}$ & $\begin{array}{c}1 / 2 \mathrm{IC}_{50} \\
(\mathrm{mg} / \mathrm{ml})\end{array}$ & $\begin{array}{c}24 \mathrm{~h} \\
48 \mathrm{~h}\end{array}$ & $72 \mathrm{~h}$ \\
\hline Leflunomide (positive control) & 0.4 & 52.11 & 0.33 & 0.15 & 23.99 & 35.12 & 53.33 \\
Crude drug & 6.0 & 51.74 & 5.32 & 2.00 & 17.01 & 41.89 & 48.62 \\
Water-boiling processed product & 3.0 & 51.83 & 2.50 & 1.50 & 22.42 & 37.24 & 48.55 \\
High-pressure steaming processed product & 3.0 & 64.82 & 2.52 & 1.80 & 21.50 & 41.26 & 48.82 \\
Excipient co-boiling processed product & 2.5 & 62.30 & 1.85 & 1.20 & 21.67 & 34.52 & 40.91 \\
WF-1 monomer component & 0.2 & 52.88 & 0.12 & 0.04 & 18.23 & 27.70 & 35.68 \\
WF-4 monomer component & 0.2 & 62.55 & 0.17 & 0.10 & 19.80 & 24.38 & 32.00 \\
\hline
\end{tabular}

WF-1, delvestidine; WF-4, anthranoyllycoctonine.

Western blot analysis. The expression of HIF-1 $\alpha$, VEGF and TLR4 proteins were evaluated using western blot analysis. Cells were collected and lysed with radioimmunoprecipitation lysis buffer (Tiangen Biotech Co., Ltd., Beijing, China). After vortexing for $20 \mathrm{sec}$, the lysis was incubated at $4^{\circ} \mathrm{C}$ for $30 \mathrm{~min}$, followed by centrifugation at $20,000 \times \mathrm{g}$ at $4^{\circ} \mathrm{C}$ for $15 \mathrm{~min}$, and then the supernatant was harvested. Protein concentrations were determined using the BCA protein assay kit (Tiangen Biotech Co., Ltd.). Protein samples were subjected to $10 \%$ SDS-PAGE (15 $\mu \mathrm{g}$ in each lane), then electronically transferred onto a polyvinylidene difluoride membrane. Following blocking with $5 \%$ bovine serum albumin (Tiangen Biotech Co., Ltd.) at room temperature for $1 \mathrm{~h}$, the membrane was incubated with mouse anti-human anti-HIF-1 $\alpha$ primary antibody (1:400 dilution; cat. no. ab463; Abcam, Cambridge, MA, USA), mouse anti-human anti-VEGF primary antibody (1:500 dilution; cat. no. ab1316; Abcam) rabbit anti-human anti-TLR4 primary antibody (1:250 dilution; cat. no. ab13867; Abcam) or rabbit anti-human anti- $\beta$-actin primary antibody (1:500 dilution; cat. no. BA2305; BOSTER, Wuhan, Hubei, China), at $4^{\circ} \mathrm{C}$ overnight. The membrane was then incubated with goat anti-rabbit immunoglobulin G (Pierce; Thermo Fisher Scientific, Inc.) at room temperature for $1 \mathrm{~h}$. Following treatment with $1 \mathrm{ml}$ SuperSignal West Pico Chemiluminescent Substrate (Thermo Scientific Inc., Inc.), protein bands were detected and analyzed with the ChemiScope mini chemiluminescent analyzer (Chemiscope 3000; CLINX, Shanghai, China). $\beta$-actin was used as an internal reference.

Enzyme-linked immunosorbent assay (ELISA). Levels of pro-inflammatory cytokines IL-6, IL- $1 \beta$ and TNF- $\alpha$ were evaluated using ELISA kits (EH004-96, EH001-96 and EH009-96, respectively; Shanghai ExCell Biology, Inc., Shanghai, China), according to the manufacturer's instructions.

Statistical analysis. Data are expressed as the mean \pm standard deviation. SPSS 19.0 software (IBM SPSS, Armonk, NY, USA) was used for statistical analysis. Student's t-test was performed for group comparisons. $\mathrm{P}<0.05$ was considered to indicate a statistically significant result.

\section{Results}

Effect of A. leucostomum Worosch. on the proliferation of HFLS-RA cells. HFLS-RA cells were treated with the crude drug, processed products (water-boiling, high-pressure steaming and excipient co-boiling processed products) and monomer components (WF-1 and WF-4), for $24 \mathrm{~h}$, then cell proliferation was assessed with a CCK-8 assay. The $\mathrm{IC}_{50}$ values for these treatments are presented in Table I. Considering that the amount of the extracted monomer was limited and high intervention concentrations (e.g., $\mathrm{IC}_{50}$ ) may be toxic, the concentrations of $1 / 2 \mathrm{IC}_{50}$ were used. Subsequently, the cells were treated with the crude drug, processed products and monomer components at the concentrations of $1 / 2 \mathrm{IC}_{50}$ for 24 , 48 and $72 \mathrm{~h}$. According to the results in Table I, the optimal inhibition effect was observed at $48 \mathrm{~h}$. Thus, in the following experiments, the drug treatment concentrations were set as $1 / 2$ $\mathrm{IC}_{50}$ values, and the treatment duration was set as $48 \mathrm{~h}$.

Analysis of cell proliferation inhibition rates indicated that, crude drug and processed products notably inhibited the cell proliferation, and the highest inhibition rate was observed in the high-pressure steaming processed product group (Table I). These results suggested that the crude drug, processed products and monomer components of A. leucostomum Worosch. may inhibit the proliferation of HFLS-RA cells, with more potent inhibition effects observed in the crude drug and processed products.

Effect of A. leucostomum Worosch. on the apoptosis rate of HFLS-RA cells. The effects of A. leucostomum Worosch. crude drug, processed products and monomer components on the apoptosis of HFLS-RA cells were evaluated using flow cytometry. The results indicated that, compared with the control group, apoptosis rates were significantly elevated in the positive control and all treatment groups (all $\mathrm{P}<0.05$; Fig. 1). Among the treatment groups, the highest apoptosis rate was observed for the water-boiling processed product group, which was significantly higher than the other treatment groups (all $\mathrm{P}<0.05$ ) and comparable to that of the positive control group. These results suggest that the crude drug, processed products 
A
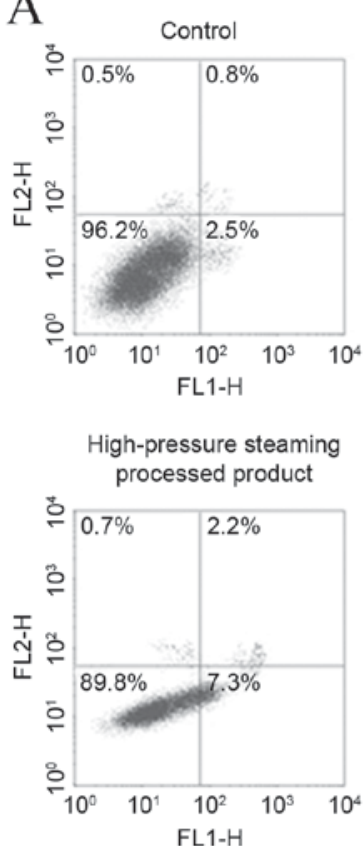
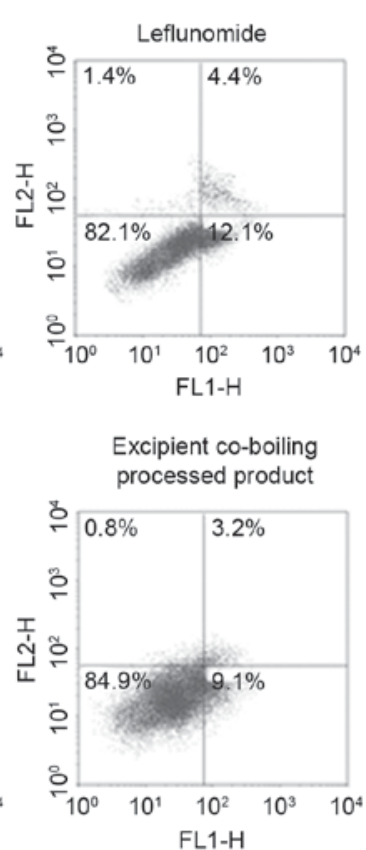

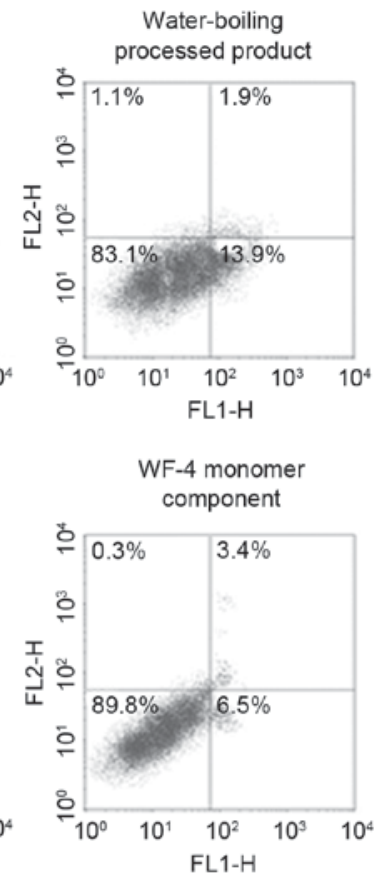

$\mathrm{B}$



Figure 1. Effect of Aconitum leucostomum Worosch. on the apoptosis rate of HFLS-RA cells. HFLS-RA cells were treated with crude drug, processed products (water-boiling, high-pressure steaming and excipient co-boiling processed products) or monomer components (WF-1 and WF-4) for 48 h. Leflunomide was used as positive control. (A) Cellular apoptosis was detected using flow cytometry. (B) Statistical analysis of the apoptosis rates. Data are presented as the mean \pm standard deviation. ${ }^{*} \mathrm{P}<0.05$ vs. control group; ${ }^{*} \mathrm{P}<0.05$ vs. crude drug group; ${ }^{\$} \mathrm{P}<0.05$ vs. water-boiling processed product group; ${ }^{\star} \mathrm{P}<0.05$ vs. high-pressure steaming processed product group. HFLS-RA, human fibroblast-like synoviocyte rheumatoid arthritis; WF-1, delvestidine; WF-4, anthranoyllycoctonine.

and monomer components of A. leucostomum Worosch. may significantly promote the apoptosis of HFLS-RA cells, and the most potent effect was observed for the water-boiling processed product.

Effect of A. leucostomum worosch. on HFLS-RA cell cycle. The effects of A. leucostomum Worosch. crude drug, processed products and monomer components on the HFLS-RA cell cycle were also evaluated using flow cytometry. These results demonstrated that, compared with the control group, the proportion of cells in the G0/G1 phase was significantly decreased in the positive control group and all treatment groups (all $\mathrm{P}<0.05$; Table II). Among the treatment groups, the lowest G0/G1 phase percentage was observed in the high-pressure steaming processed product group, which was significantly lower than the other treatment groups $(\mathrm{P}<0.05$; Table II). These results suggest that the crude drug, processed products and monomer components of A. leucostomum Worosch. may induce cell cycle arrest in HFLS-RA cells; the most potent effect was observed for the high-pressure steaming processed product.

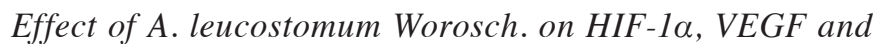
TLR4 expression in HFLS-RA cells. To investigate the 
Table II. Effects of Aconitum leucostomum Worosch. on the human fibroblast-like synoviocyte rheumatoid arthritis cell cycle.

\begin{tabular}{llll}
\hline Treatment & G0/G1 phase $(\%)$ & S-phase $(\%)$ & G2/M phase $(\%)$ \\
\hline Control & $72.03 \pm 1.10$ & $14.50 \pm 0.92$ & $13.47 \pm 0.46$ \\
Leflunomide & $56.83 \pm 0.67^{\mathrm{a}}$ & $24.73 \pm 1.25^{\mathrm{a}}$ & $18.43 \pm 1.76^{\mathrm{a}}$ \\
Crude drug & $55.17 \pm 3.98^{\mathrm{a}}$ & $27.77 \pm 3.86^{\mathrm{a}}$ & $17.7 \pm 2.83$ \\
Water-boiling processed product & $54.60 \pm 2.47^{\mathrm{a}}$ & $25.13 \pm 2.58^{\mathrm{a}}$ & $20.27 \pm 4.24^{\mathrm{a}}$ \\
High-pressure steaming processed product & $52.57 \pm 2.14^{\mathrm{a}-\mathrm{d}}$ & $25.57 \pm 3.81^{\mathrm{a}}$ & $21.87 \pm 2.71^{\mathrm{a}}$ \\
Excipient co-boiling processed product & $56.77 \pm 1.30^{\mathrm{a}, \mathrm{e}}$ & $25.73 \pm 0.87^{\mathrm{a}}$ & $17.5 \pm 0.98^{\mathrm{a}, \mathrm{e}}$ \\
WF-1 monomer component & $59.33 \pm 1.78^{\mathrm{a}, \mathrm{b}, \mathrm{c}, \mathrm{e}}$ & $25.50 \pm 1.76^{\mathrm{a}}$ & $15.17 \pm 0.90^{\mathrm{c}, \mathrm{e}}$ \\
WF-4 monomer component & $59.10 \pm 2.11^{\mathrm{a}, \mathrm{b}, \mathrm{c}, \mathrm{e}}$ & $26.27 \pm 1.66^{\mathrm{a}}$ & $14.63 \pm .55^{\mathrm{c}, \mathrm{e}}$ \\
\hline
\end{tabular}

${ }^{\mathrm{a}} \mathrm{P}<0.05$ vs. control group; ${ }^{\mathrm{b}} \mathrm{P}<0.05$ vs. crude drug group; ${ }^{\mathrm{c}} \mathrm{P}<0.05$ vs. water-boiling processed product group; ${ }^{\mathrm{d}} \mathrm{P}<0.05$ vs. excipient co-boiling processed product; ${ }^{\mathrm{e}} \mathrm{P}<0.05$ vs. high-pressure steaming processed product group. WF-1, delvestidine; WF-4, anthranoyllycoctonine.

effects of A. leucostomum Worosch. crude drug, processed products and monomer components on the expression of HIF-1 $\alpha$, VEGF and TLR4 in HFLS-RA cells, mRNA and protein levels were measured using RT-qPCR and western blot analysis, respectively. Results from RT-qPCR indicated that, compared with the control group, levels of HIF-1 $\alpha$ and TLR4 mRNA were significantly downregulated in the positive control group and all treatment groups (all $\mathrm{P}<0.05$; Fig. 2A and C). Compared with the control group, only slight changes in VEGF mRNA levels were observed in the water boiling and excipient co-boiling processed product groups, as well as in the monomer component (WF-1 and WF-4) groups ( $\mathrm{P}>0.05$; Fig. 2B). Results from western blot analysis indicated that, compared with the control group, there were decreases in the expression of HIF-1 $\alpha$, VEGF and TLR4 proteins in the crude drug, processed product and monomer component groups (Fig. 3). These results suggest that the crude drug, processed products and monomer components of A. leucostomum Worosch. may downregulate the expression of HIF-1 $\alpha$, VEGF and TLR4 in HFLS-RA cells.

Effect of A. leucostomum Worosch. on pro-inflammatory cytokine levels in cell culture supernatant. The effects of A. leucostomum Worosch. crude drug, processed products and monomer components on the pro-inflammatory cytokine levels in the culture supernatant of HFLS-RA cells were detected with ELISA. The results indicated that, compared with the control group, levels of IL- 6 , IL-1 $\beta$ and TNF- $\alpha$ in the cell culture supernatant were all significantly decreased in the treatment groups (all $\mathrm{P}<0.05$; Fig. 4). These results suggest that the crude drug, processed products and monomer components of A. leucostomum Worosch. may decrease pro-inflammatory cytokine levels in HFLS-RA cells.

\section{Discussion}

RA is pathologically characterized by synovitis, in which the pathologically altered synovial membrane enhances inflammatory cell infiltration and increased pro-inflammatory cytokine release causes hypoxia in the joint microenvironment and leads to angiogenesis and pannus formation (27). Pannus has been associated with erosion, which may eventually result in joint cartilage and bone destruction (28). Pannus formation serves a key role in the occurrence and development of RA, and HIF-1 $\alpha$ is a key regulator of the hypoxia response in the body. Brouwer et al (29) demonstrated that HIF-1 $\alpha$ expression is upregulated in the synovial tissue in patients with RA and that the number of HIF- $1 \alpha^{+}$cells in the RA synovial tissue is positively correlated with the blood vessel number and inflammation cell infiltration. Another study indicated that synovial hyperblastosis and vascular density was increased in RA patients (30). Furthermore, it has been reported that the serum level of HIF-1 $\alpha$ is significantly elevated in patients with early-stage RA and is even higher than in patients with advanced-stage or stable RA (7). In addition, it has been determined that the serum level of VEGF is increased in patients with RA (31).

TLRs are involved in the regulation of adaptive immune responses in the body, and they serve key roles in the pathogenesis and development of various autoimmune diseases, particularly RA (32). Most activated TLRs can induce the antimicrobial defense system to produce IL- $6, \mathrm{IL}-1 \beta$ and TNF- $\alpha$. Therefore, the innate immune response may be involved in the pathogenesis of RA.

In the present study, HFLS-RA cells were treated with A. leucostomum Worosch. crude drug, processed products and monomer components. Cell proliferation was assessed using a CCK-8 assay, and apoptosis and the cell cycle were evaluated with flow cytometry. The results demonstrated that drug treatments could markedly inhibit the proliferation of HFLS-RA cells. Furthermore, the drug treatments significantly elevated the apoptosis rates of these cells, and decreased the proportion of cells in G0/G1 phase. These results suggested that $A$. leucostomum Worosch. may induce apoptosis and inhibit proliferation of HFLS-RA cells. The expression of HIF-1 $\alpha$, VEGF and TLR4 mRNA and protein in the HFLS-RA subjected to drug treatments were evaluated using RT-qPCR and western blot analysis, and levels of IL-6, IL-1 $\beta$ and TNF- $\alpha$ in the cell culture supernatant were detected with ELISA. A previous study demonstrated that hypoxic conditions are closely associated with upregulated levels of HIF-1 $\alpha$ and VEGF (33). However, the results of the present study demonstrated that, compared with the control group, the drug treatments significantly decreased the mRNA and 


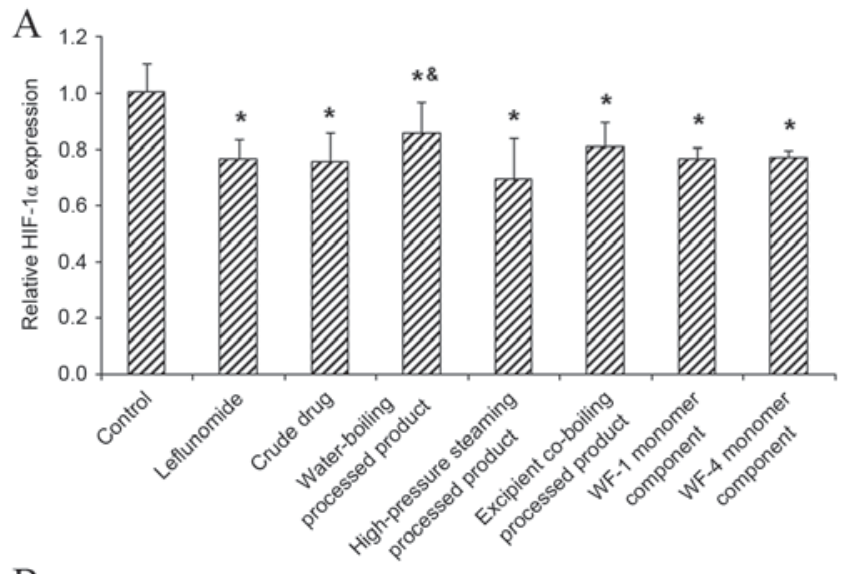

B


Figure 2. Effect of Aconitum leucostomum Worosch. on the expression of HIF-1 $\alpha$, VEGF and TLR4 mRNA in HFLS-RA cells. HFLS-RA cells were treated with the crude drug, processed products (water-boiling, high-pressure steaming and excipient co-boiling processed products) or monomer components (WF-1 and WF-4) for $48 \mathrm{~h}$. Leflunomide was used as a positive control. The expression of (A) HIF-1 $\alpha$, (B) VEGF and (C) TLR4 mRNA in HFLS-RA cells were evaluated using reverse transcription-quantitative polymerase chain reaction. Data are presented as mean \pm standard deviation. ${ }^{*} \mathrm{P}<0.05$ vs. control group; ${ }^{*} \mathrm{P}<0.05$ vs. crude drug group; ${ }^{\circledR} \mathrm{P}<0.05$ vs. high-pressure steaming processed product group. HFLS-RA, human fibroblast-like synoviocyte rheumatoid arthritis; WF-1, delvestidine; WF-4, anthranoyllycoctonine; HIF-1 $\alpha$, hypoxia-inducible factor- $1 \alpha$; VEGF, vascular endothelial growth factor; TLF4, Toll-like receptor 4.

protein levels of HIF-1 $\alpha$ and TLR4 in HFLS-RA cells, but not VEGF. Furthermore, it was demonstrated that, compared with the control group, levels of IL-6, IL-1 $\beta$ and TNF- $\alpha$ in the cell culture supernatant were significantly decreased, which was in accordance with previous results (4).

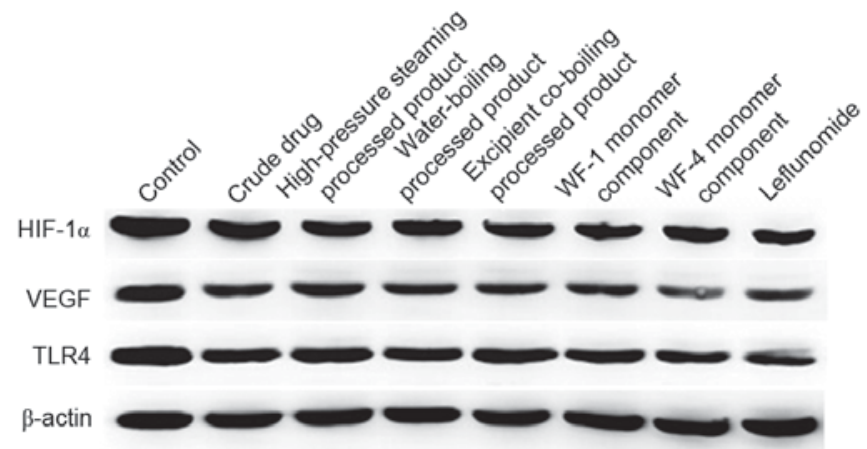

Figure 3. Effect of Aconitum leucostomum Worosch. on the expression of HIF-1 $\alpha$, VEGF and TLR4 protein in HFLS-RA cells. HFLS-RA cells were treated with the crude drug, processed products (water-boiling, high-pressure steaming and excipient co-boiling processed products) or monomer components (WF-1 and WF-4) for $48 \mathrm{~h}$. Leflunomide was used as a positive control. The expression of HIF-1 $\alpha$, VEGF and TLR4 protein in HFLS-RA cells were evaluated using western blot analysis. HFLS-RA, human fibroblast-like synoviocyte rheumatoid arthritis; WF-1, delvestidine; WF-4, anthranoyllycoctonine; HIF-1 $\alpha$, hypoxia-inducible factor-1 $\alpha$; VEGF, vascular endothelial growth factor; TLF4, Toll-like receptor 4.

In the present study, our results showed that, persistent hypoxia may induce the upregulated expression of HIF-1 $\alpha$ and TLR4, which, together with the enhanced release of pro-inflammatory cytokines, may contribute to enhanced synovial inflammation. $\mathrm{Ca}^{2+} /$ calmodulin-dependent protein kinase II (CaMKII) is a member of the CaMK family and is expressed in the fibroblast-like synovial cells in RA. It has been determined that CaMKII may regulate the transcription and activation of HIF- $1 \alpha$ and other factors, and inhibiting CaMKII may downregulate the expression of HIF- $1 \alpha$ and VEGF in RA synovial cells, potentially by suppressing the pI3K/Akt signaling pathway (34). The $\mathrm{pI} 3 \mathrm{~K} / \mathrm{Akt}$ and mitogen-activated protein kinase signaling pathways mediate the activation of HIF-1 $\alpha$ in RA synovial cells under hypoxic conditions (35). It has been demonstrated that treatment with artesunate may inhibit the pI3 K/Akt signaling pathway and downregulate the expression of HIF-1 $\alpha$ and VEGF in RA fibroblast-like synovial cells (36). Another study indicated that inhibition of the pI3 K/Akt signaling pathway reduced HIF-1 $\alpha$ expression in rat models of collagen-induced arthritis, which significantly alleviated arthritis clinical symptoms, imaging alterations, synovial hyperplasia and inflammatory cell infiltration (37). Therefore, HIF-1 $\alpha$ may be activated via various pathways by receptors in the RA fibroblast-like synovial cells in a hypoxic microenvironment (38).

In conclusion, the current results indicated that the crude drug, processed products and monomer components of A. leucostomum Worosch. significantly enhanced the apoptosis of HFLS-RA cells, with the most potent effect observed for water-boiling processed products. The A. leucostomum treatments induced cell cycle arrest in the HFLS-RA cells, with the most potent effect observed for high-pressure steaming processed products. Furthermore, the A. leucostomum treatments downregulated the expression levels of HIF-1 $\alpha$ and TLR4 in HFLS-RA cells, and decreased the pro-inflammatory cytokine levels in the culture supernatant. These findings may 


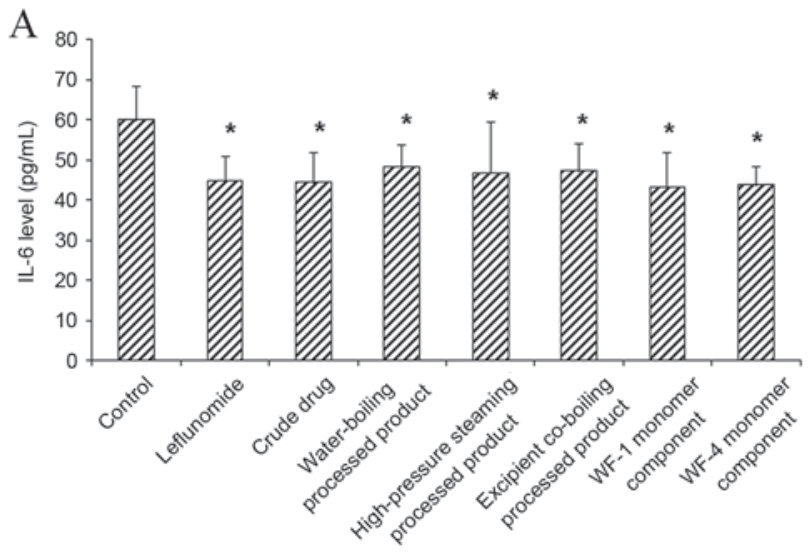

B
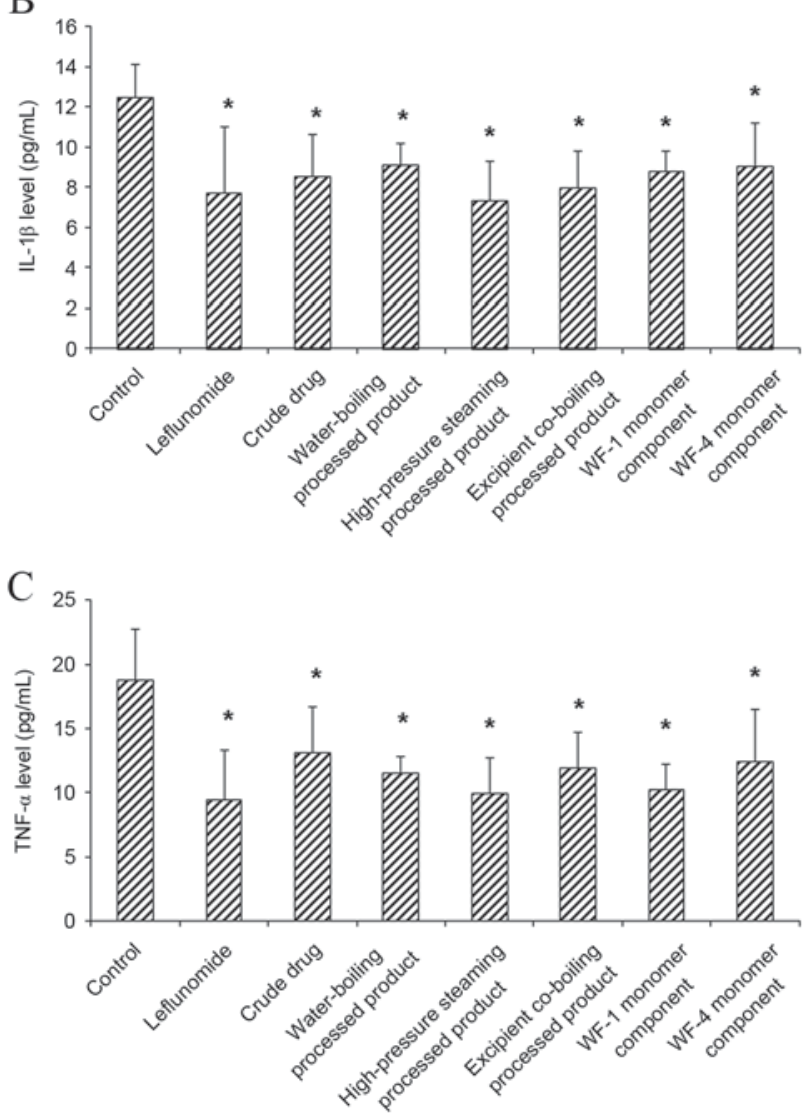

Figure 4. Effect of Aconitum leucostomum Worosch. on the pro-inflammatory cytokine levels in the culture supernatant of HFLS-RA cells. HFLS-RA cells were treated with the crude drug, processed products (water-boiling, high-pressure steaming and excipient co-boiling processed products) or monomer components (WF-1 and WF-4) for $48 \mathrm{~h}$. Leflunomide was used as a positive control. Levels of (A) IL-6, (B) IL-1 $\beta$ and (C) TNF- $\alpha$ in the cell culture supernatant were detected using ELISA kits. Data are presented as mean \pm standard deviation. ${ }^{*} \mathrm{P}<0.05$ vs. control group. HFLS-RA, human fibroblast-like synoviocyte rheumatoid arthritis; WF-1, delvestidine; WF-4, anthranoyllycoctonine; IL, interleukin; TNF- $\alpha$, tumor necrosis factor- $\alpha$.

contribute to understanding of the pathogenesis and development of RA and the development of novel therapeutic strategies to clinically treat the disease.

\section{Acknowledgements}

The present study was supported by the National Natural Science Foundation of China (grant no. 81160498).

\section{References}

1. Seyler TM, Park YW, Takemura S, Bram RJ, Kurtin PJ, Goronzy JJ and Weyand CM: BLyS and APRIL in rheumatoid arthritis. J Clin Invest 115: 3083-3092, 2005.

2. Yamaannishi Y and Firestein GS: Pathogenesis of rheumatoid arthritis: The role of synoviocytes. Rheum Dis Clin North Am 27: 355-371, 2001

3. Wang JB and Pan L: Etiology and pathogenesis of rheumatoid arthritis. Shandong Yi Yao Za Zhi 42: 69-70, 2002.

4. Perlman H, Pagliari LJ, Liu H, Koch AE, Haines GK III and Pope RM: Rheumatoid arthritis synovial macrophages express the Fas-associated death domain-like interleukin-lbeta-converting enzyme-inhibitory protein and are refractory to Fas-mediated apoptosis. Arthritis Rheum 44: 21-30, 2001.

5. Sivakumar B, Akhavani MA, Winlove CP, Taylor PC, Paleolog EM and Kang N: Synovial hypoxia as a cause of tendon rupture in rheumatoid arthritis. J Hand Surg Am 33: 49-58, 2008.

6. Konisti S, Kiriakidis S and Paleolog EM: Hypoxia-a key regulator of angiogenesis and inflammation in rheumatoid arthritis. Nat Rev Rheumatol 8: 153-162, 2012.

7. Huang X, Chen Y and Gong L: Measurement of serum hypoxia inducible factor-1 $\alpha$ in patients with rheumatoid arthritis and the correlation with ultrasonographic assessment of synovial lesions. Zhejiang Med J 33: 1420-1422, 2011.

8. Del Rey MJ, Izquierdo E, Usategui A, Gonzalo E, Blanco FJ, Acquadro F and Pablos JL: The transcriptional response of normal and rheumatoid arthritis synovial fibroblasts to hypoxia. Arthritis Rheum 62: 3584-3594, 2010.

9. You P, Lin M, Li K, Ye X and Zheng J: Normobaric oxygen therapy inhibits HIF-1 $\alpha$ and VEGF expression in perihematoma and reduces neurological function defects. Neuroreport 27: 329-336, 2016.

10. Cheng S, He C, Zhou H, Kong X, Xie H, Xia L and Yan J: The effect of Toll-like receptor 4 on $\beta 2$-glycoprotein I-induced B cell activation in mouse model. Mol Immunol 71: 78-86, 2016.

11. Huang B, Wang QT, Liu KK, Jiang L and Wei W: The relationship between TNF- $\alpha$ signaling pathway and CD $4+\mathrm{T}$ cells in the development of rheumatoid arthritis. Zhong Guo Yao Li Xue Tong Bao 29: 900-903, 2013.

12. Xiao JY, Wang BS and Wang SJ: Expression of IL-1 and TNF- $\alpha$ in adjuvant arthritis rat models. J Emer Trad Chin Med 20: 607-608, 2011

13. Manfredi AA, Baldini M, Camera M, Baldissera E, Brambilla M, Peretti G, Maseri A, Rovere-Querini P, Tremoli E, Sabbadini MG and Maugeri N: Anti-TNFo agents curb platelet activation in patients with rheumatoid arthritis. Ann Rheum Dis 75: 1511-1520, 2016.

14. Cacciapaglia F, Anelli MG, Rizzo D, Morelli E, Scioscia C, Mazzotta D, Iannone F and Lapadula G: Influence of TNF- $\alpha$ inhibition on oxidative stress of rheumatoid arthritis patients. Reumatismo 67: 97-102, 2015.

15. Wang XK, Li B, Ren Y, Liang ZC and Yang ZB: Effects of Alcohol Extract of toddalia asiatica on the Inflammation-associated cytokines of model rats with Adjuvant arthritis. Zhong Guo Yao Fang 27: 3524-3527, 2016.

16. Editorial Committee of Flora of China, China Academy of Sciences: Flora of China. Vol 27. Chinese Science Publishing and Media Ltd., Beijing, pp113-326, 1979.

17. Xin Xu: Bahaerguli Huangerhan. Kazakh Pharmacopeia. Vol 1. Ethnic Publishing House, Beijing, pp45-47, 2009.

18. Meng Q, Liang J and Wu G: Advances in pharmacological effects of alkaloids. Lishizhen Med Materia Med Res 14: 700-702, 2003.

19. Xinjiang Institute of Biological Soil Desert: Xinjiang Medicinal Flora. Vol 1. Xinjiang People's Publishing House, Urumqi, 1977.

20. Editorial Committee of Flora of Xinjiang: Flora of Xinjiang. Vol 1. Xinjiang Science and Technology Health Press, Urumqi, 1999

21. Yang JL, Lu J, Liu J and Nie JH: Effects of Diphtheria Aconitum and processed products on adjuvant-induced arthritis rat model. Chinese Medicine 37: 2495-2501, 2015.

22. Wang F, Zhao J, Zhao F and Nie J: Study on the chemical constituents of Aconitum leucostomum Worosch. China Pharmacy 26: 1233-1235, 2015.

23. Wu M and Wei Y: Ethnobotany of Aconitum in Xinjiang. Chinese Wild Plant Resources 23: 29-30, 2004 (In Chinese).

24. Editorial Committee of Chinese Pharmacopoeia: Chinese Pharmacopoeia. Vol 1. Chinese Medical Science and Technology Press, Beijing, pp33-34, 2010. 
25. Wiacek R, Kolossa K, Jankowski T, Jeka S, Karmowski A, Karmowski M and Gworys B: The efficacy and safety of leflunomide in patients with active rheumatoid arthritis. Adv Clin Exp Med 21: 337-342, 2012.

26. Livak KJ and Schmittgen TD: Analysis of relative gene expression data using real-time quantitative PCR and the 2(-Delta Delta C(T)) Method. Methods 25: 402-408, 2001.

27. Chen L, Wang WS, Wang YM and Shi CH: The expression of VEGF and TGF- $\beta 1$ in synovial membrane of the patients of Knee joint pannus. Shi He Zi Da Xue Xue Bao (Zi Ran Ke Xue Ban) 28: 72-75, 2010.

28. Shiozawa S, Tsumiyama K, Yoshida K and Hashiramoto A: Pathogenesis of joint destruction in rheumatoid arthritis. Arch Immunol Ther Exp (Warsz) 59: 89-95, 2011.

29. Brouwer E, Gouw AS, Posthumus MD, van Leeuwen MA, Boerboom AL, Bijzet J, Bos R, Limburg PC, Kallenberg CG and Westra J: Hypoxia inducible factor-1-alpha (HIF-1alpha) is related to both angiogenesis and inflammation in rheumatoid arthritis. Clin Exp Rheumatol 27: 945-951, 2009.

30. Shankar J, Thippegowda PB and Kanum SA: Inhibition of HIF-1alpha activity by BP-1 ameliorates adjuvant induced arthritis in rats. Biochem Biophys Res Commun 387: 223-228, 2009.

31. Huang XQ, Chen Y, Chen LB, Gong LM, Xie BH, Peng Y, Huang H, Xin XF, Wu XD and Zhang Z: Measurement of serum vascular endothelial growth factor, angiopoietin-1 and angiopoietin-2 in patients with rheumatoid arthritis and the correlation with synovial lesions. Chin J Rheumatol 16: 679-683, 2012 (In Chinese).

32. Migita K, Miyashita T, Maeda Y, Nakamura M, Yatsuhashi H, Kimura H, Ishibashi $\mathrm{H}$ and Eguchi K: Toll-like receptor expression in lupus peripheral blood mononuclear cells. J Rheumatol 34: 493-500, 2007.
33. Ning $X$ and Lu ZJ: Expression of Fibrosis-related Cytokine in Budd-Chiari Syndrome. Chin Gen Prac 18: 2026-2029, 2015.

34. Chou LW, Wang J, Chang PL and Hsieh YL: Hyaluronan modulates accumulation of hypoxiainducible factor- 1 alpha, inducible nitric oxide synthase, and matrix metalloproteinase- 3 in the synovium of rat adjuvant-induced arthritis model. Arthritis Res Ther 13: R90, 2011.

35. Westra J, Brouwer E, van Roosmalen IA, Doornbos-van der Meer B, van Leeuwen MA, Posthumus MD and Kallenberg CG: Expression and regulation of HIF-1alpha in macrophages under inflammatory conditions; significant reduction of VEGF by CaMKII inhibitor. BMC Musculoskelet Disord 11: 61, 2010.

36. Aletaha D, Neogi T, Silman AJ, Funovits J, Felson DT, Bingham CO III, Birnbaum NS, Burmester GR, Bykerk VP, Cohen MD, et al: 2010 Rheumatoid arthritis classification criteria: An American college of rheumatology/european league against rheumatism collaborative initiative. Arthritis Rheum 62: 2569-2581, 2010

37. Hochberg MC, Altman RD, Brandt KD, Clark BM, Dieppe PA, Griffin MR, Moskowitz RW and Schnitzer TJ: Guidelines for the medical management of osteoarthritis. Part II. Osteoarthritis of the knee. American College of Rheumatology. Arthritis Rheum 38: 1541-1546, 1995.

38. Cramer T, Yamanishi Y, Clausen BE, Förster I, Pawlinski R, Mackman N, Haase VH, Jaenisch R, Corr M, Nizet V, et al: HIF-1alpha is essential for myeloid cell-mediated inflammation. Cell 112: 645-657, 2003. 